\title{
Purification and Comparison of Outer Membrane Protein P2 from Haemophilus influenzae Type b Isolates
}

\author{
Robert S. Munson, Jr., Jerry L. Shenep, Stephen J. Barenkamp, and \\ Dan M. Granoff, Edward Mallinckrodt Department of Pediatrics, \\ Washington University School of Medicine, and the Division of Infectious \\ Diseases, St. Louis Children's Hospital, St. Louis, Missouri 63178
}

A B S T R A C T Haemophilus influenzae type b isolates have been subdivided based on differences in major outer membrane protein (OMP) profiles resolved on gradient and modified Laemmli sodium dodecyl sulfate-polyacrylamide gel electrophoresis systems. Although 21 subtypes have been observed, $86 \%$ of invasive isolates have one of five common subtypes and $71 \%$ of isolates have one of three subtypes. In isolates with two of the most common outer membrane subtypes, one major OMP has an apparent molecular weight of 37,000 . In isolates with another common OMP subtype, a cross-reactive protein with an apparent molecular weight of 36,500 is observed. All three proteins have been designated P2. Protein P2 from these prototype isolates was solubilized with Zwittergent 3-14 and purified to homogeneity. Based on amino acid compositions, cyanogen bromide cleavage products, staphylococcal V8 protease, and chymotryptic peptide maps, the $\mathrm{P} 2$ protein from the three isolates has been highly conserved. Rabbit antibody prepared against P2 from one strain was cross-reactive with P2 isolated from the other two heterologous strains by Western blot. This antibody passively protected infant rats against type b Haemophilus infection caused by the homologous organism, but not against challenge by a strain with the heterologous $36,500 \mathrm{~mol}$ wt P2 protein. Thus, although the $\mathrm{P} 2$ protein from isolates with different OMP subtypes are closely related, the protection experiments suggest that determinants on

This work was presented in part at the Annual Meeting of the Americn Society for Microbiology, Atlanta, Georgia, March 1982 and the Workshop on Haemophilus influenzae by Type b Vaccine, National Institutes of Health, Bethesda, Maryland, August 1982.

Address all correspondence to Dr. Munson, Division of Infectious Diseases, St. Louis Children's Hospital, $500 \mathrm{~S}$. Kingshighway Blvd., P. O. Box 14871, St. Louis, MO.

Received for publication 29 November 1982 and in revised form 30 March 1983. the cell surface interacting with protective antibody may be strain or subtype specific.

\section{INTRODUCTION}

Haemophilus influenzae type $\mathrm{b}(\mathrm{Hib})^{1}$ is a major cause of bacterial meningitis and other invasive infections in young children. Children of the susceptible age lack antibody to the Hib capsular polysaccharide and children under $1 \mathrm{yr}$ of age generally respond poorly to the presently available capsule-based vaccines. In contrast, children of this age group respond vigorously to protein vaccines (1), and outer membrane proteins (OMP) of this organism appear to be immunogenic during natural infection (2). Recently, Lam et al. (3) demonstrated that passive administration of antibody directed against noncapsular antigens of Hib-protected infant rats against Hib bacteremia after intraperitoneal challenge. Shenep et al. (4) extended these observations by demonstrating that anti-lipopolysaccharide (LPS) antibodies lacked protective activity. In contrast, antibodies directed against OMP appeared to confer protection. In these experiments, antibodies directed against several OMP were detected in the protective immune sera by whole cell radioimmune precipitation, which suggests that some OMP epitopes on the surface of these encapsulated organisms were accessible to antibody. One protein detected in these preparations was a 37,000-D major OMP designated P2. We report the purification and partial characterization of the major OMP P2 from three strains of Hib that are representative of the previously described

\footnotetext{
${ }^{1}$ Abbreviations used in this paper: cfu, colony forming units; ELISA, enzyme-linked immunosorbent assay; Hib, Haemophilus influenzae type b; LPS, lipopolysaccharide; OMP, outer membrane protein; PRP, polyribosyl-ribitol phosphate; SDS-PAGE, sodium dodecyl sulfate-polyacrylamide gel electrophoresis.
} 
OMP subtypes $1 \mathrm{H}, 2 \mathrm{~L}$, and $3 \mathrm{~L}$ (5). Antibody prepared against purified $\mathrm{P} 2$ from the $1 \mathrm{H}$ strain passively protects infant rats against experimental infection when challenged with the organism from which the immunogen was prepared. In contrast, this antibody preparation failed to protect against bacteremia when rats were challenged with the OMP subtype $2 \mathrm{~L}$ organism.

\section{METHODS}

Bacterial isolates. Invasive Hib isolates (from patients with meningitis or bacteremia) were obtained, typed, and stored as previously described (5). Three prototype isolates, Minn $A, b_{3} a$ (Durst), and Corn, which are representative of OMP subtypes $1 \mathrm{H}, 2 \mathrm{~L}$, and $3 \mathrm{~L}$, were employed in these studies. Isolates were cloned on chocolate agar, and grown overnight at $37^{\circ} \mathrm{C}$ in a $5 \% \mathrm{CO}_{2}$ atmosphere in brain-heart infusion broth (Difco Laboratories, Inc., Detroit, MI) supplemented with $2 \mu \mathrm{g} / \mathrm{ml}$ each of hemin and nicotinamideadenine dinucleotide. Overnight cultures were diluted 1:25 in fresh broth $(500 \mathrm{ml} / 2,000 \mathrm{ml}$ Erlenmeyer flask) and grown to late-log phase at $37^{\circ} \mathrm{C}$ in a rotary shaker-incubator (model no. G25; New Brunswick Scientific Co., Inc., Edison, NJ) at $250 \mathrm{rpm}$. Cells were harvested by centrifugation and stored at $-20^{\circ} \mathrm{C}$.

Purification of P2. Frozen cells $(\sim 18 \mathrm{~g}$, wet wt) were suspended in $50 \mathrm{ml}$ of $10 \mathrm{mM}$ Hepes, pH 7.4, and sonicated 10 times for $15 \mathrm{~s}$ at $0-4^{\circ} \mathrm{C}$. Large debris and whole cells were removed by centrifugation at $1,700 \mathrm{~g}$ for $20 \mathrm{~min}$ at $4^{\circ} \mathrm{C}$. The total membrane fraction was then harvested at $105,000 \mathrm{~g}$ for $1 \mathrm{~h}$. The pellet was suspended in $10 \mathrm{mM}$ Hepes, $\mathrm{pH} \mathrm{7.4}$, at protein concentration of $10 \mathrm{mg} / \mathrm{ml}$. Cytoplasmic membrane proteins were solubilized by dilution of the total membrane fraction with 1 vol of $2 \%$ sodium lauryl-sarcosinate in $10 \mathrm{mM}$ Hepes, $\mathrm{pH}$ 7.4. After $30 \mathrm{~min}$ at room temperature, the insoluble residue was collected by centrifugation at $105,000 \mathrm{~g}$ for $1 \mathrm{~h}$ at $4^{\circ} \mathrm{C}$. Subsequent steps were performed at room temperature. The pellet was suspended in $2 \%$ sodium deoxycholate, $0.2 \mathrm{M}$ sodium chloride, $5 \mathrm{mM}$ EDTA, and $50 \mathrm{mM}$ Tris-Cl, pH 8.0, harvested after $30 \mathrm{~min}$, and then washed once in the same buffer. Protein P2 was then solubilized by suspension of the pellet in $0.4 \% \mathrm{Zwit}$ tergent 3-14 (Calbiochem-Behring Corp., La Jolla, CA) buffered with $25 \mathrm{mM}$ imidazole at $\mathrm{pH} 6.5$. After $30 \mathrm{~min}$, the insoluble fraction was removed by centrifugation at 105,000 g. Triton X-100 (Packard Instrument Co., Inc., Downers Grove, IL) was added to the soluble fraction to a final concentration of $0.5 \%$ and the preparation was applied to DEAE-Sephacel equilibrated with $25 \mathrm{mM}$ imidazole, $0.4 \%$ Zwittergent 3-14, and 0.5\% Triton X-100, pH 6.5. Optimal results were obtained with application of $\sim 1 \mathrm{mg}$ of protein/ milliter of DEAE-Sephacel. The column was washed with two column volumes of the same buffer containing $0.05 \mathrm{M}$ $\mathrm{KCl}$ and $\mathrm{P} 2$ was eluted with a linear gradient of $0.05-0.4$ $\mathrm{M} \mathrm{KCl}$ in the same buffer (total of seven column volumes). P2 was the predominant protein in the sample and eluted as a single peak (Fig. 1). Protein-containing fractions were assessed for purity by sodium dodecyl sulfate-polyacrylamide gel electrophoresis (SDS-PAGE), and pooled.

PAGE. SDS-PAGE was carried out in 4-24\% gels and in $11 \%$ modified Laemmli gels according to the method of Lugtenberg and co-workers, as previously described (5). These gel systems have previously been used by us to subtype $\mathrm{Hib}$ isolates (5) and to examine OMP heterogeneity of nontypable Haemophilus isolates (6). Chemically and enzymatically digested samples were analyzed on modified Laemmli gels containing $15 \%$ polyacrylamide as well as on gradient gels.

Chemical and enzymatic digestions. Cyanogen bromide cleavage of P2 from the different prototype strains was conducted in 70\% formic acid (7). 40- $\mu$ g aliquots of purified P2

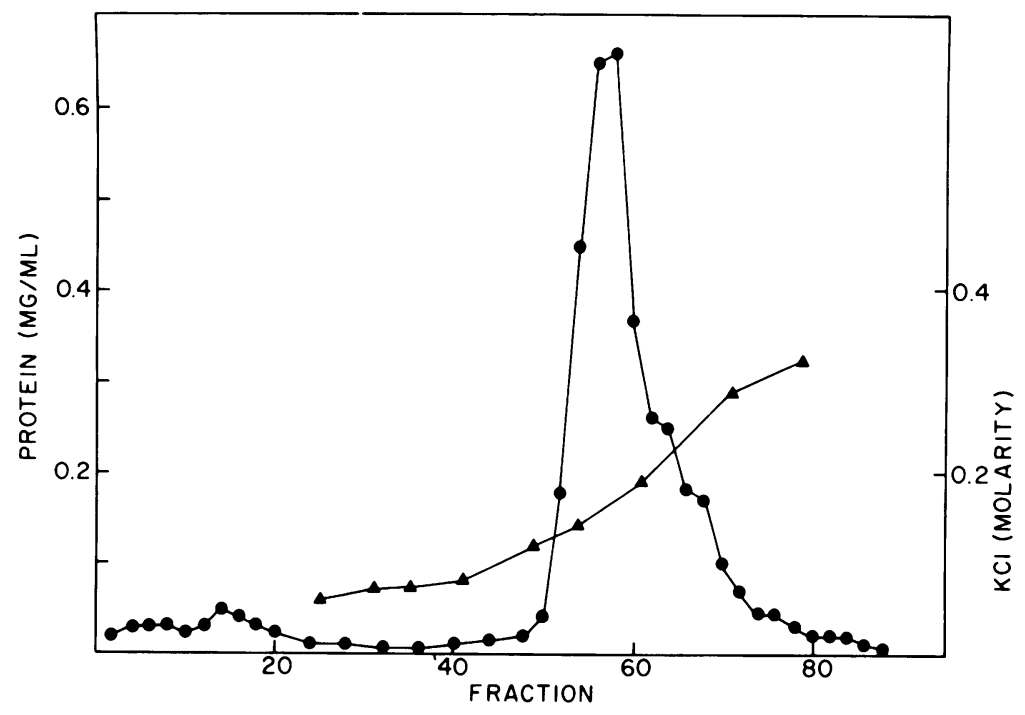

FIGURE 1 DEAE-Sephacel chromatography of P2. $8.3 \mathrm{mg}$ of the Zwittergent-soluble fraction was applied to $7-\mathrm{ml}(1.6 \times 3.6 \mathrm{~cm})$ DEAE-Sephacel column and eluted as described in the text. 0.5 -ml fractions were collected. Protein concentration $(\bullet)$ was determined by Peterson's modification (11) of the Lowry method and $\mathrm{KCl}$ molarity $(\Delta)$ was determined by conductivity. 
were precipitated by addition of 2 vol of ethanol. Precipitates were recovered by low speed centrifugation after overnight incubation at $-20^{\circ} \mathrm{C}$, washed once with ethanol, drained well, and suspended in $50 \mu \mathrm{l}$ of $\mathbf{7 0 \%}$ formic acid or $70 \%$ formic acid containing $50 \mathrm{mg} / \mathrm{ml}$ of cyanogen bromide. After a 3-h incubation in the dark at $37^{\circ} \mathrm{C}$, samples were diluted to $1 \mathrm{ml}$ with water. Peptides were concentrated, freed of formic acid and cyanogen bromide by lyophilization, incubated at $100^{\circ} \mathrm{C}$ for $5 \mathrm{~min}$ in Laemmli sample buffer, and analyzed by SDS-PAGE.

Proteolytic cleavage with straphylococcal V8 protease (Miles Laboratories Inc., Elkhart, IN) was performed essentially as described by Cleveland et al. (8). 80- $\mu \mathrm{g}$ samples were precipitated with ethanol as described above and suspended in $0.5 \%$ SDS, $10 \%$ glycerol, $0.001 \%$ bromphenol blue, $0.125 \mathrm{M}$ Tris-Cl, pH 6.8 , at $1 \mathrm{mg} / \mathrm{ml}$. Samples were solubilized by incubation at $100^{\circ} \mathrm{C}$ for $2 \mathrm{~min}$ and subjected to proteolysis at room temperature with $0.4 \mu \mathrm{g}$ of $\mathrm{V} 8$ protease. The reaction was terminated by incubation at $100^{\circ} \mathrm{C}$ for 5 min after addition of 1 vol of $20 \%$ SDS, $4 \% \beta$-mercaptoethanol. Peptides were analyzed by SDS-PAGE.

Chymotryptic ${ }^{125}$ I-peptide maps of purified P2 were prepared by the method of Elder et al. (9) as described by Swanson (10). Ethanol-precipitated protein $(40 \mu \mathrm{g})$ was solubilized with $1 \%$ SDS, $0.1 \mathrm{M}$ Tris-Cl, pH 6.8 , at $100^{\circ} \mathrm{C}$ for $5 \mathrm{~min}$. Samples were iodinated with chloramine $\mathrm{T}$ and quenched with Laemmli sample buffer containing $5 \% \beta$ mercaptoethanol. Free iodine was removed by SDS-PAGE employing the modified Laemmli system. Stained proteins were cut out of the gel, washed with $10 \%$ methanol, treated with $N$-p-tosyl-L-lysine chloromethyl ketone-treated chymotrypsin, and analyzed as previously described (10).

Analytical techniques and reagents. Protein was determined by the method of Lowry as modified by Peterson (11) employing bovine serum albumin (BSA) as the standard. Amino acid analysis was performed on a Durrum D-500 analyzer (Dionex Corp., Sunnyvale, CA) by the protein chemistry facility (Department of Biological Chemistry, Washington University School of Medicine) on evacuated samples hydrolyzed in $6 \mathrm{~N} \mathrm{HCl}$ for $24 \mathrm{~h}$ at $110^{\circ} \mathrm{C}$. LPS was determined by limulus lysate gelation using $E$. coli LPS as the standard according to the directions of the manufacturer (Associates of Cape Cod, Woods Hole, MA). Unless noted, reagents were purchased from Sigma Chemical Co., St. Louis, MO.

Antisera and serology. Purified P2 was freed from detergent by ethanol precipitation. Precipitated protein was suspended in phosphate-buffered saline (PBS) and emulsified in 1 vol of Freund's complete adjuvant. Rabbits were injected at several sites subcutaneously with a total of $100 \mu \mathrm{g}$ of protein. 5 and 6 wk later, animals were injected similarly with $100 \mu \mathrm{g}$ of protein emulsified in incomplete Freund's adjuvant and bled 1 and 5 wk later.

Anticapsular antibody in these sera was determined by radioimmune assay using ${ }^{3} \mathrm{H}$-labeled $\mathrm{Hib}$ capsule as described by Kuo and co-workers (12). Anti-LPS and anti-P2 antibodies were quantitated by enzyme-linked immunosorbent assay (ELISA) (13). For measurement of anti-LPS antibody, LPS was prepared from the Minn A isolate by the hot phenol method and characterized as described previously (13). For measurement of anti-P2 antibody, purified P2 was precipitated with ethanol to remove detergent, suspended in PBS, and diluted to $2 \mu \mathrm{g} / \mathrm{ml}$ in carbonate coating buffer at $\mathbf{p H}$ 9.6. EIA plates (Flow Labs, Inc., McLean, VA) were coated with LPS or P2 overnight at $37^{\circ} \mathrm{C}$. The following day, assays were performed as described by Shenep et al. (13), using a goat anti-rabbit IgG-alkaline phosphatase con- jugate (Sigma Chemical Co.). Western blot analysis was performed as described by Towbin et al. (14).

Anti-LPS and anti-polyribosyl-ribitol phosphate (PRP) antibodies were removed from anti-P2 antisera by absorption with LPS-Sepharose and PRP-Sepharose, respectively. LPS-Sepharose preparation and antibody absorptions were performed as previously described (13). For preparation of PRP-Sepharose, PRP was purified from the supernatant of stationary phase broth cultures by sequential precipitation with ethanol, Cetavlon, and ethanol, as described by Kuo and co-workers (12). The final PRP precipitate was dissolved in $20 \mathrm{mM}$ sodium phosphate, $\mathrm{pH} 6.9$, and residual contaminants were removed by absorption with hydroxylapatite. Protein and nucleic acid content of the final product ( 2 and $0.7 \%$, respectively) were determined by UV absorption (15). LPS content of the final product was $<0.06 \%$ by limulus lysate gelation. PRP-Sepharose was prepared by coupling cyanogen bromide-activated PRP to $\omega$-aminohexyl-Sepharose (Pharmacia Fine Chemicals, Piscataway, NJ) using methods similar to those of Robbins and Schneerson (16). PRP (3.0 $\mathrm{mg}$ in $1 \mathrm{ml}$ of water) was activated by treatment with $46 \mathrm{mg}$ of cyanogen bromide $(1 \mathrm{ml})$ at room temperature while the $\mathrm{pH}$ was maintained at 10.8 with sodium hydroxide. After $10 \mathrm{~min}, 1 \mathrm{ml}$ of $0.1 \mathrm{M} \mathrm{NaHCO}$ was added and the solution was brought to $\mathrm{pH} 8.3$ with $\mathrm{HCl}$. $1 \mathrm{~g}$ of $\omega$-aminohexyl-Sepharose, that had been previously swollen and washed in $0.1 \mathrm{M} \mathrm{NaHCO}$, was added and incubation continued overnight at $4^{\circ} \mathrm{C}$ with gentle mixing. Residual reactive groups were blocked with ethanolamine at $\mathrm{pH} 8.0$ and the product was washed extensively with PBS. Antisera were absorbed with PRP-Sepharose for $2 \mathrm{~h}$ at room temperature with gentle agitation. After collection of the unabsorbed fraction, the PRP-Sepharose was washed extensively with PBS containing $0.5 \%$ BSA. Affinity pure anti-PRP was eluted from the column with $3.5 \mathrm{M} \mathrm{MgCl}_{2}$, diluted immediately with 1 vol of PBS-albumin, and dialyzed against PBS. AntiPRP antibody was determined by radioimmune assay as described above.

Experimental infection. 5-d-old infant rats were injected subcutaneously with $0.1 \mathrm{ml}$ of dilutions of serum antibody fractions or PBS-albumin. $1 \mathrm{~d}$ later, animals were challenged with $10^{2}$ to $10^{3} \mathrm{Hib}$ colony forming units (cfu) by intraperitoneal injection as described by Lam et al. (3). Quantitative bacterial cultures of blood were obtained $18 \mathrm{~h}$ later as previously described (3).

\section{RESULTS}

The major OMP of $\mathrm{Hib}$ are Triton X-100-insoluble $(3,5,17)$ and sarcosyl-insoluble $(5)$, as are the OMP of other gram-negative organisms $(18,19)$. Unlike proteins from enteric microorganisms, however, treatment of whole cells or total membrane preparations of $\mathrm{Hib}$ with $2 \% \mathrm{SDS}$ at $60^{\circ} \mathrm{C}(20)$ resulted in solubilization of all envelope proteins, precluding differential solubility in SDS as a strategy for purification of these OMP. Solubilization with Triton X-100 in the presence of EDTA was marginally effective and poorly reproducible. Therefore, alternative strategies were sought. Deoxycholate/sodium chloride effectively solubilized most of the minor proteins in the sarcosylinsoluble fraction as well as the majority of Hib-LPS. Treatment of the insoluble residue with $\mathrm{Zwittergent}$ 
3-14 at a slightly acidic pH preferentially solubilized protein P2. Zwittergent, as well as selectively solubilizing P2, had the added advantage of being compatible with ion exchange chromatographic techniques $(21,22)$. Thus, the Zwittergent soluble fraction was applied to DEAE-Sephacel for removal of residual contaminants. The DEAE step was the only step where significant loss of protein P2 was observed; typical recoveries were on the order of $50 \%$ for this step. SDSPAGE analysis of the various fractions is shown in Fig. 2. The final preparation appeared to be homogenous by SDS-PAGE (Fig. 2).

LPS, an outer membrane glycolipid which is frequently detectable in OMP preparations (20), was determined by limulus lysate analysis in two independent P2 preparations. One contained $1.1 \%$ and the other 3.3\% LPS by weight.

We have previously demonstrated strain heterogeneity among the major Hib OMP of isolates of Hib. OMP profiles of prototype isolates that represent the three most common subtypes are shown in Fig. 3. When examined on the modified Laemmli gel, protein P2 from subtype $2 \mathrm{~L}$ isolates has a slightly lower apparent molecular weight $(36,500)$ than that of the corresponding protein in outer membrane preparations from subtype $1 \mathrm{H}$ and $3 \mathrm{~L}$ organisms, which have an apparent molecular weight of 37,000 . This difference is more apparent in the 4-24\% gradient gel (Fig. 3). To further compare P2 from the prototype strains, we purified this protein from each strain as described above. In all preparations, the differential detergent solubilities and DEAE-elution profiles were similar.

The amino acid composition, cyanogen bromide

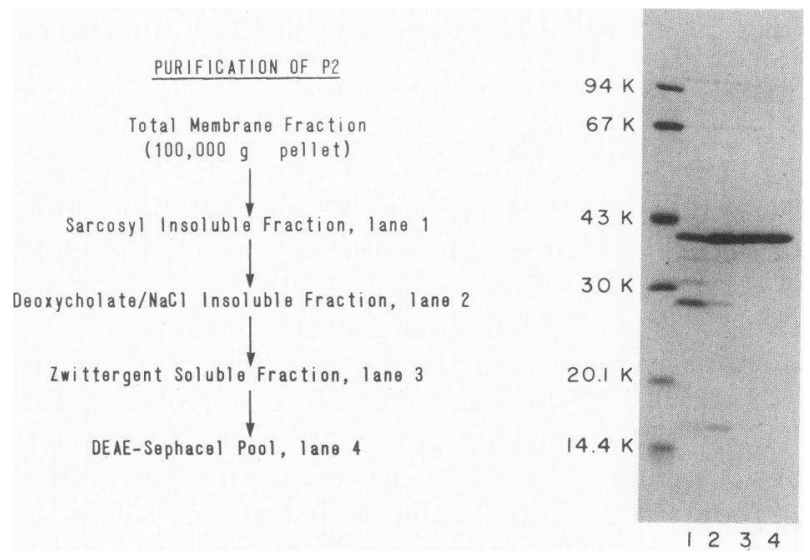

Figure 2 Protein P2 from Hib strain 1 Minn A (subtype 1H) has been purified to homogeneity by differential detergent extraction and DEAE-Sephacel chromatography. The fractions indicated in the flow chart are shown on the gel. Lanes 1 and 2 contained $10 \mu \mathrm{g}$ of protein and lanes 3 and 4 contained $4 \mu \mathrm{g}$ of protein.
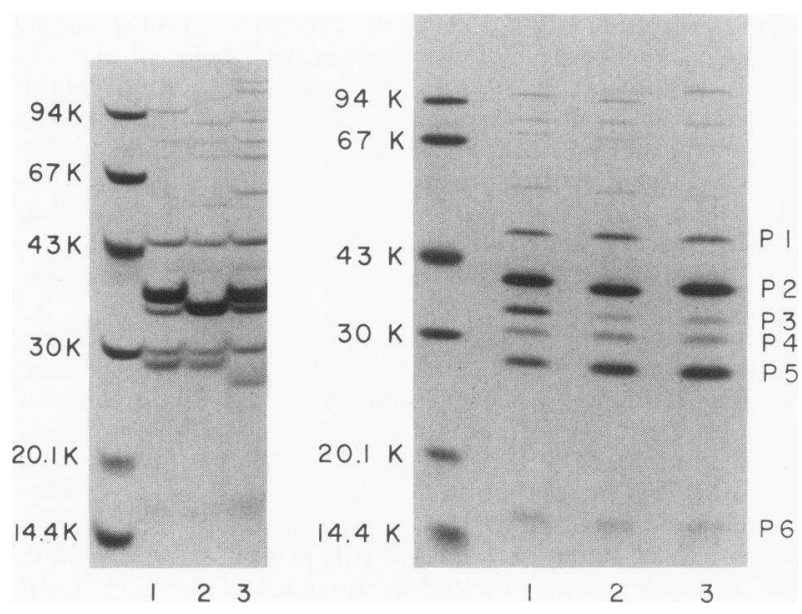

Figure $3 H$. influenzae isolates have been subdivided into 21 subtypes based on their outer membrane profiles. The 4$24 \%$ polyacrylamide gel gradient patterns of subtypes $1 \mathrm{H}$, $2 \mathrm{~L}$, and $3 \mathrm{~L}$ are shown on the left panel (lanes 1,2 , and 3 , respectively) and account for $71 \%$ of invasive isolates examined (26). Although clearly distinguishable on the gradient gel, the three strains show similar protein profiles on the Laemmli gel (lanes 1, 2, and 3, respectively, right panel). The major peptides have been designated Pl to P6 (right panel). The unlabeled lanes are molecular weight standards.

cleavage pattern, and peptide maps of the three proteins were then compared. The amino acid composition of the proteins is shown in Table I and is similar

TABLE I

Amino Acid Composition of P2

\begin{tabular}{lrrr}
\hline & Minn A & Durst & Corn \\
\hline & & mole \% & \\
Asp & 12.6 & 12.3 & 10.6 \\
Thr & 6.9 & 6.7 & 7.1 \\
Ser & 5.2 & 4.8 & 5.4 \\
Glu & 11.7 & 11.5 & 12.3 \\
Pro & 0.6 & $\mathrm{ND}^{\circ}$ & 0.8 \\
Gly & 12.2 & 11.7 & 13.0 \\
Ala & 7.7 & 7.3 & 8.2 \\
Val & 5.3 & 5.9 & 6.0 \\
Ile & 5.9 & 7.7 & 2.9 \\
Leu & 8.4 & 9.9 & 7.2 \\
Tyr & 4.5 & 4.6 & 6.5 \\
Phe & 3.1 & 3.1 & 3.8 \\
His & 2.1 & 1.9 & 2.5 \\
Lys & 8.8 & 8.3 & 9.0 \\
Arg & 4.7 & 4.4 & 4.9 \\
Met & 0.12 & ND $^{\circ}$ & ND $^{\circ}$ \\
\hline
\end{tabular}

- ND, not detected. Analyses were performed on 24-h hydrolysates and uncorrected for losses. Tryptophan and $1 / 2$ cysteinyl were not determined. 
for each of the proteins. Cyanogen bromide cleavage of the proteins in $70 \%$ formic acid resulted in the generation of two peptides from each of the proteins (Fig. 4). The lower apparent molecular weight of P2 from the OMP subtype $2 \mathrm{~L}$ strain is reflected in a lower apparent molecular weight of the largest cleavage product. Purified P2 proteins were also treated with staphylococcal V8 protease according to the method of Cleveland (8) and examined by SDS-PAGE (Fig. 5). Increased digestion times or increased protease concentrations resulted in further degradation of the large peptide into poorly resolved low molecular weight peptides (data not shown). To increase the resolution of the peptide maps, we iodinated the purified proteins by the chloramine $T$ technique and examined the chymotryptic peptides by thin-layer electrophoresis and chromatography. Autoradiographs of the iodinated peptides are shown in Fig. 6. As in the previous analysis, the three proteins gave similar cleavage products.

Antibody to purified P2 (subtype $1 \mathrm{H}$ ) was prepared by immunization of rabbits with antigen emulsified in Freund's adjuvant. Hyperimmune serum contained antibody directed against both Hib LPS and P2, as measured by ELISA (Table II). After absorption of anti-LPS antibody with LPS-Sepharose (13), the specificity of anti-P2 antibody was determined by Western blot using total membrane proteins from the prototype isolates as the antigens. This antiserum reacted exclusively with P2; therefore, antibodies directed against

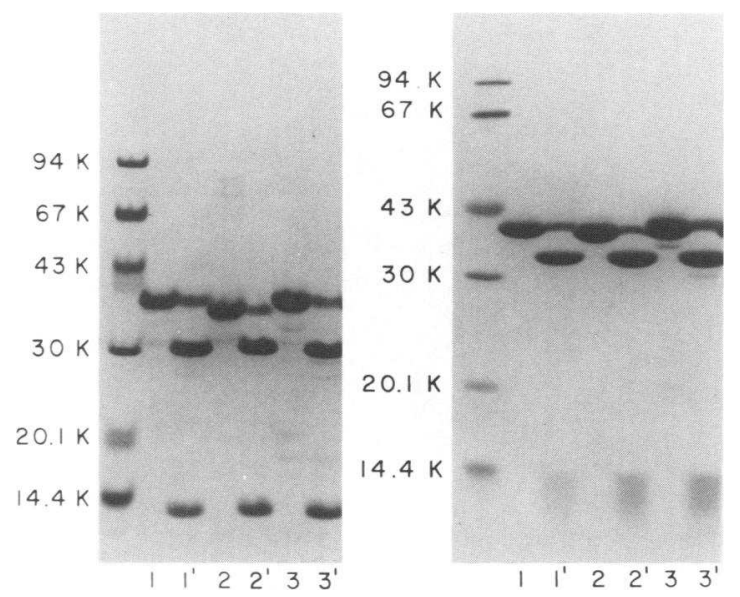

Figure $440 \mu \mathrm{g}$ of purified P2 from each of the prototype strains was treated with $2.5 \mathrm{mg}$ of $\mathrm{CNBr}$ in $70 \%$ formic acid, lyophilized, and subjected to SDS-PAGE. Control preparations were treated with $70 \%$ formic acid without $\mathrm{CNBr}$. The left panel is a 4-24\% gradient gel; the right panel is a $15 \%$ Laemmli gel. Formic acid-treated $\mathrm{P} 2$ preparations from the $1 \mathrm{H}, 2 \mathrm{~L}$, and $3 \mathrm{~L}$ strains are shown in lanes 1,2 , and 3 , respectively. The CNBr-treated preparations are in lanes $\mathrm{l}^{\prime}$, $2^{\prime}$, and $3^{\prime}$, respectively. In each $\mathrm{CNBr}$-treated preparation, two cleavage products are observed.
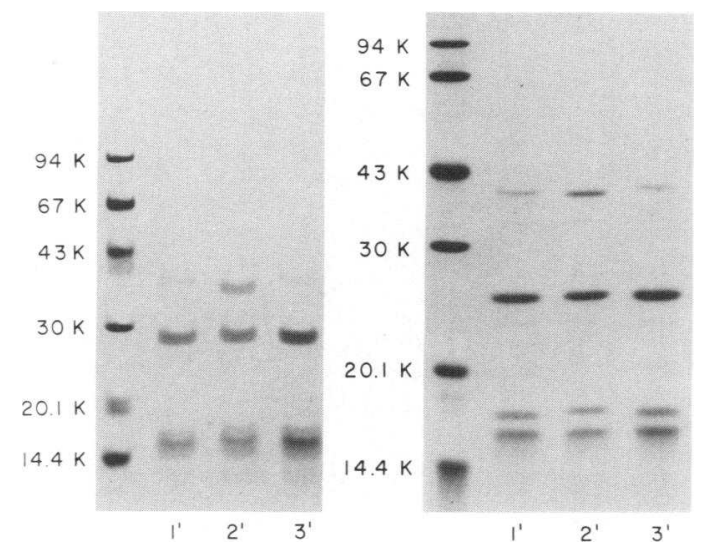

Figure 5 V8 protease treatment of P2. $80 \mu \mathrm{g}$ of purified P2 from each of the prototype strains was treated with 0.4 $\mu \mathrm{g}$ of $\mathrm{V} 8$ protease in $0.5 \%$ SDS for $60 \mathrm{~min}$ at room temperature and subjected to SDS-PAGE. The left panel is a 4-24\% gradient gel; the right panel is a $15 \%$ Laemmli gel. The treated proteins are shown in lanes $1^{\prime}, 2^{\prime}$, and $3^{\prime}$ (preparations from the $1 \mathrm{H}, 2 \mathrm{~L}$, and $3 \mathrm{~L}$ strains, respectively). Untreated proteins are not shown.

other membrane proteins were not detected (Fig. 7, lane 1). However, P2 from the other prototype strains cross-reacted extensively by this method (Fig. 7, lanes 2 and 3 ).

OMP have been considered as potential vaccine candidates for the prevention of diseases caused by Haemophilus $(3,23)$ and other gram-negative bacteria $(24$, 25). Therefore, anti-P2 antibody was examined for its ability to protect infant rats from Hib bacteremia. Sera were absorbed sequentially with PRP-Sepharose and LPS-Sepharose. Adequacy of absorption of anti-PRP and anti-LPS antibodies was monitored by radioimmune assay and ELISA, respectively (Table II). A 1:2 dilution of anti-P2 antiserum protected six of seven infant rats that were challenged with the homologous Hib strain Minn A (subtype $1 \mathrm{H}$ ), and a 1:8 dilution completely protected three of seven rats and significantly lowered the level of bacteremia in the remaining four animals (Table III). Surprisingly, the same serum fraction did not protect against challenge by a heterologous Hib strain, Durst, our prototype OMP subtype $2 \mathrm{~L}$ isolate; six of seven animals were bacteremic at the 1:2 dilution (Table IV). Affinity-purified anti-PRP antibody, which was previously shown to protect infant rats against $\mathrm{Hib}$ bacteria, protected seven of seven rats challenged with strain Minn A, and six of six rats challenged with strain Durst (Tables III and IV, respectively).

\section{DISCUSSION}

P2 is the major OMP observed in SDS-PAGE analysis of sarcosyl-insoluble Hib outer membrane prepara- 

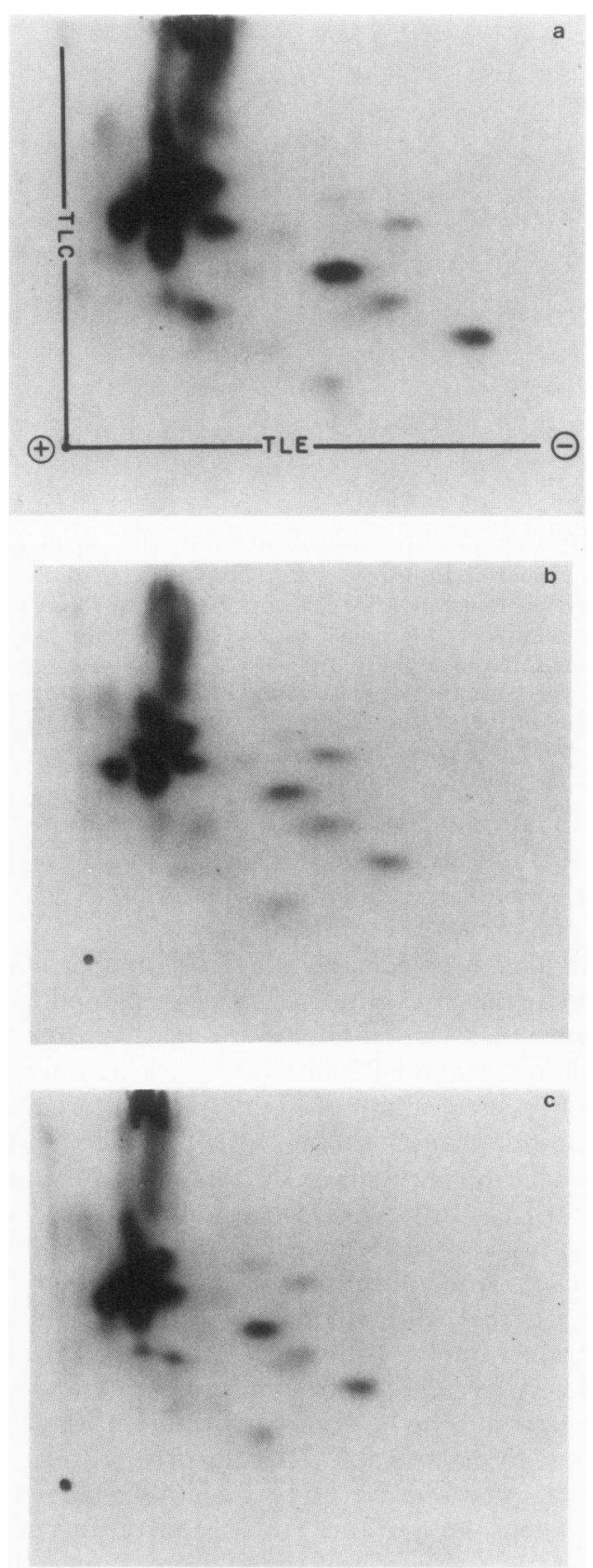

Figure 6 Chymotryptic peptide maps of P2, iodinated with chloramine $T$, were prepared from each of the prototype strains. Peptides were separated by thin-layer electrophoresis (TLE) which was followed by thin-layer chromatography (TLC). Peptides were visualized by autoradiography. Preparations from the $1 \mathrm{H}, 2 \mathrm{~L}$, and $3 \mathrm{~L}$ strains are shown in panels $a, b$, and $c$, respectively.

tions. In previous experiments, anti-P2 antibody was detected in hyperimmune whole cell antisera containing non-PRP, non-LPS antibodies that protected against
TABLE II

Serologic Analysis of Anti-P2 Antiserum

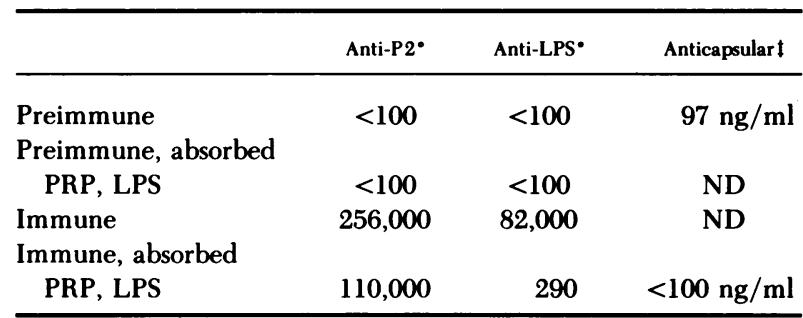

- ELISA data expressed as the reciprocal dilution of antibody yielding an 0.2 absorbance after $60 \mathrm{~min}$ of incubation.

$\downarrow$ Radioimmunoassay employing ${ }^{3} \mathrm{H}-\mathrm{PRP}$ as described by Kuo and co-workers (12).

experimental $\mathrm{Hib}$ infection caused by the homologous strain (4). Thus, we purified P2 from three Hib strains with different OMP subtypes. The purified proteins from all three strains had similar peptide maps, were all cleaved into two fragments by cyanogen bromide, and had nearly identical amino acid compositions. The apparent molecular weight of the subtype $2 \mathrm{~L}$ protein is slightly lower than that of the other two proteins. Conformational differences or nonamino acid constit-

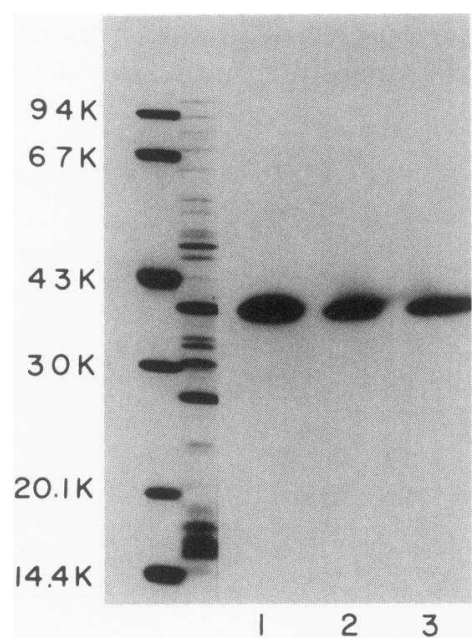

Figure 7 Immunological cross-reactivity of P2 from the three prototype strains. Rabbit antiserum was prepared against purified P2 (Minn A, subtype $1 \mathrm{H}$ ) and analyzed by Western blot against total membrane fractions derived from the prototype $1 \mathrm{H}, 2 \mathrm{~L}$, and $3 \mathrm{~L}$ strains (lanes 1,2 , and 3 , respectively). Total membrane proteins (15 $\mu \mathrm{g} /$ lane) were separated on the Laemmli gel system, transferred to nitrocellulose (Bio-Rad Laboratories, Richmond, CA), and sequentially incubated with rabbit anti-P2 antiserum at $\mathbf{a}^{1 / 200}$ dilution and ${ }^{125}$ I-labeled protein A. Immune complexes were detected by autoradiography. Molecular weight standards and a Coomassie Blue-stained total membrane fraction are shown on the left. 
TABLE III

Passive Protection of Infant Rats by Anti-P2 Antibody

\begin{tabular}{cccc}
\hline & \multicolumn{3}{c}{ Homologous challenge } \\
\cline { 2 - 4 } Serum & Dilution & $\begin{array}{c}\text { No. bacteremic/ } \\
\text { No. challenged }\end{array}$ & $\begin{array}{c}\text { Geometric } \\
\text { mean }\end{array}$ \\
\hline & & & $c f u / m l$ blood \\
Preimmune, absorbed & $1 / 2$ & $7 / 7$ & 16,000 \\
$\quad$ PRP, LPS & $1 / 2$ & $1 / 7$ & $<10$ \\
$\begin{array}{c}\text { Anti-P2, absorbed } \\
\text { PRP, LPS }\end{array}$ & $1 / 8$ & $3 / 7$ & 178 \\
$\begin{array}{c}\text { Anti-P2, absorbed } \\
\text { PRP, LPS }\end{array}$ & - & $0 / 7$ & $<10$ \\
Anti-PRP (500 ng) & & & \\
\hline
\end{tabular}

Rabbit antiserum was prepared against purified $\mathrm{P} 2$ from Hib strain Minn A (subtype 1H). Sera were absorbed with PRP-Sepharose and LPS-Sepharose and administered subcutaneously to infant rats. The following day, rats were challenged intraperitoneally with $200 \mathrm{cfu}$ of strain Minn A

uents might account for this strain-dependent difference in apparent molecular weight. Alternatively, the absence of a peptide in the $\mathrm{P} 2$ protein from the subtype $2 \mathrm{~L}$ isolate might account for its increased SDS-PAGE gel mobility. However, no missing peptide was identified in the two-dimensional chymotryptic peptide maps. Rabbit antibody prepared against protein P2 from Hib strain Minn A cross-reacted by Western blot analysis with the P2 protein from strains Corn and Durst. Thus, although the P2 protein from strain Durst is different in apparent molecular weight by SDSPAGE analysis, the analytic and serologic data indicate that the P2 proteins from strains with these three subtypes are highly conserved gene products.

Antiserum prepared against P2 (Minn A, subtype

TABLE IV

Passive Protection of Infant Rats by Anti-P2 Antibody

\begin{tabular}{lccc}
\hline \multirow{2}{*}{\multicolumn{1}{c}{ Serum }} & \multicolumn{3}{c}{ Heterologous challenge } \\
\cline { 2 - 4 } & Dilution & $\begin{array}{c}\text { No. bacteremic/ } \\
\text { No. challenged }\end{array}$ & $\begin{array}{c}\text { Geometric } \\
\text { mean }\end{array}$ \\
\hline & & & $c f u / m l$ blood \\
PBS-A & - & $5 / 6$ & 300 \\
Anti-P2 absorbed PRP, LPS & $1 / 2$ & $6 / 7$ & 1315 \\
Anti-PRP (500 ng) & - & $0 / 6$ & $<10$ \\
\hline
\end{tabular}

Rabbit antiserum was prepared against purified $\mathbf{P} 2$ from strain Minn A (subtype $1 \mathrm{H}$ ). Serum fractions were prepared and administered as described in Table III. Infant rats were challenged intraperitoneally with $200 \mathrm{cfu}$ of strain Durst, the prototype OMP subtype $2 \mathrm{~L}$ isolate.
1H) and absorbed to remove anti-PRP and anti-LPS antibody passively protected infant rats against $\mathrm{Hib}$ bacteremia caused by the homologous Minn A isolate; this suggests that epitopes of $\mathrm{P} 2$ are accessible at the cell surface. In contrast, administration of this same antibody preparation did not prevent experimental bacteremia caused by a Hib isolate with the heterologous outer membrane subtype $2 \mathrm{~L}$. Specificity of anti-P2 antiserum was independently confirmed by immunofluorescence. Whole cells were incubated sequentially with anti-P2 antiserum prepared as described above, washed, and then incubated with fluorescein isothiocyanate-labeled goat anti-rabbit IgG. Strong immunofluorescence was observed with the homologous strain (Minn A) and 11 of 12 other independent OMP subtype $1 \mathrm{H}$ isolates, but not with the heterologous subtype 2L strain, Durst. One of five independent OMP $2 L$ isolates and one of five independent OMP $3 \mathrm{~L}$ isolates were also strongly fluorescent. Thus, although the P2 proteins from isolates with different OMP subtypes are closely related, the cross protection and immunofluorescence experiments indicate that P2 determinants that are exposed on the cell surface and interact with protective antibody are to a large extent OMP subtype or strain specific. Similarly, antiserum prepared against whole cells (strain Eagan, OMP subtype $1 \mathrm{~L}$ ) and absorbed to remove anti-PRP and anti-LPS antibody was previously shown by us to protect infant rats challenged with the homologous strain, Eagen (4), as well as to protect against bacteremia caused by another randomly chosen OMP subtype $1 \mathrm{~L}$ organism (unpublished data). However, this antiserum failed to protect against bacteremia caused by strain Durst, the strain with OMP subtype $2 \mathrm{~L}$ (4).

Hansen and co-workers (23) have recently demonstrated that monoclonal antibody directed against an OMP with an apparent molecular weight of 39,000 protected infant rats against Hib bacteremia. In these experiments, protection was also shown to be strain specific. The monoclonal antibody used by Hansen et al. (23) has recently been found by us to react with protein $\mathrm{P} 2$ in 18 of 21 invasive subtype $3 \mathrm{~L}$ isolates tested, but in none of 36 subtype $1 \mathrm{~L}, 1 \mathrm{H}, 2 \mathrm{~L}$, and $2 \mathrm{H}$ isolates examined to date (unpublished data). Thus, data from experiments using both monoclonal antibody and conventional antisera indicate that protein P2 with an apparent molecular weight estimated between 37,000 and 39,000 (23) is an effective immunogen in eliciting strain-specific protective anti-OMP antibody in both mice and rabbits. Furthermore, P2 purified by solubilization with Zwittergent retains strain-specific immunogenic surface determinants responsible for eliciting protective antibody. These data support the value of continued investigations of the role of OMP in inducing immunity against Hib disease 
in humans and the possible, eventual inclusion of OMP in prototype vaccines for human use.

\section{ACKNOWLEDGMENTS}

We thank Susan Grass for her superb technical assistance, Dr. Eric Hansen for his anti-39,000-D OMP monoclonal antibody, and Dr. J. S.-C. Kuo for ${ }^{3} \mathrm{H}$-labeled PRP. We also thank Drs. Luis Glaser and Donald Krogstad for reviewing the manuscript.

This work was supported by Public Health Service grants AI 17572 and I-T32-AI 07172 from the National Institute of Allergy and Infectious Diseases.

\section{REFERENCES}

1. South, M. A. 1960. Lack of immune response to Haemophilus influenzae: immune paralysis or immaturity. J. Pediatr. 80:348-350.

2. Gulig, P. A., G. H. McCracken, C. V. Frisch, K. H. Johnston, and E. J. Hansen. 1982. Antibody response of infants to cell surface exposed outer membrane proteins of Haemophilus influenzae type b after systemic Haemophilus disease. Infect. Immun. 37:82-88.

3. Lam, J. S., D. M. Granoff, J. R. Gilsdorf, and J. W. Costerton. 1980. Immunogenicity of outer membrane derivatives of Haemophilus influenzae type b. Curr. Microbiol. 3:359-364.

4. Shenep, J. L., S. J. Barenkamp, R. S. Munson, Jr., and D. M. Granoff. 1982. Role of capsular and noncapsular antibodies in protection against experimental Haemophilus influenzae type b infection. Pediatr. Res. 16:250A. (Abstr.)

5. Barenkamp, S. J., R. S. Munson, Jr., and D. M. Granoff. 1981. Subtyping isolates of Haemophilus infuenzae type b by outer-membrane protein profiles. J. Infect. Dis. 143:668-676.

6. Barenkamp, S. J., R. S. Munson, Jr., and D. M. Granoff. 1982. Outer membrane protein and biotype analysis of pathogenic nontypable Haemophilus influenzae. Infect. Immun. 36:535-540.

7. Gross, E. 1967. The cyanogen bromide reaction. Methods Enzymol. 11:238-255.

8. Cleveland, D. W., S. G. Fischer, M. W. Kirschner, and U. K. Laemmli. 1977. Peptide mapping by limited proteolysis in sodium dodecyl sulfate and analysis by gel electrophoresis. J. Biol. Chem. 252:1102-1106.

9. Elder, J. H., R. A. Pickett, II, J. Hampton, and R. Lerner. 1977. Radioiodination of proteins in single polyacrylamide gel slices. J. Biol. Chem. 252:6510-6515.

10. Swanson, J. 1979. Studies on Gonococcus infection. XVIII. ${ }^{125}$ I-labeled peptide mapping of the major protein on the gonococcal cell wall outer membrane. Infect. Immun. 23:799-810.

11. Peterson, G. L. 1977. A simplification of the protein assay method of Lowry et al. which is more generally applicable. Anal. Biochem. 83:346-356.
12. Kuo, J. S.-C., N. Monji, R. S. Schwabe, and D. W. McCoy 1981. A radioactive antigen-binding assay for the measurement of antibody to Haemophilus influenzae type b capsular polysaccharide. J. Immunol. Methods. 43:3547.

13. Shenep, J. L., R. S. Munson, Jr., and D. M. Granoff. 1982. Human antibody responses to lipopolysaccharide after meningitis due to Haemophilus influenzae type b. J. Infect. Dis. 145:181-190.

14. Towbin, H., T. Staehelin, and J. Gordon. 1979. Electrophoretic transfer of proteins from polyacrylamide gels to nitrocellulose sheets: procedure and some applications. Proc. Natl. Acad. Sci. USA. 76:4350-4354.

15. Kalb, V. F., and R. W. Bernlohr. 1977. A new spectrophotometric assay for protein in cell extracts. Anal. Biochem. 82:362-371.

16. Robbins, J. B., and R. Schneerson. 1974. Immunoadsorbents. Methods Enzymol. 34:703-722.

17. Loeb, M. R., and D. H. Smith. 1980. Outer membrane protein composition in disease isolates of Haemophilus influenzae: pathogenic and epidemiological implications. Infect. Immun. 30:709-717.

18. Filip, C., G. Fletcher, J. L. Wulff, and C. F. Earhart. 1973. Solubilization of the cytoplasmic membrane of Escherichia coli by the ionic detergent sodium-lauryl sarcosinate. J. Bacteriol. 115:717-722.

19. Schnaitman, C. A. 1971. Solubilization of the cytoplasmic membrane of Escherichia coli by Triton X-100. J. Bacteriol. 108:545-552.

20. Osborn, M. J., and H. C. P. Wu. 1980. Proteins of the outer membrane of gram-negative bacteria. Annu. Rev. Microbiol. 34:369-422.

21. Gonenne, A., and R. Ernst. 1978. Solubilization of membrane proteins by sulfobetaines, novel Zwitterionic surfactants. Anal. Biochem. 87:23-28.

22. Blake, M. S., and E. C. Gotschlich. 1982. Purification and partial characterization of the major outer membrane protein of Neisseria gonorrheae. Infect. Immun. $36: 277-283$.

23. Hansen, E. J., S. M. Robertson, P. A. Gulig, C. F. Frisch, and E. J. Hanes. 1982. Immunoprotection of rats against Haemophilus influenzae type $b$ disease mediated by monoclonal antibody against a Haemophilus outermembrane protein. Lancet. I:366-368.

24. Frasch, C. E., and M. S. Peppler. 1982. Protection against group B Neisseria meningitidis disease: preparation of soluble protein and protein-polysaccharide immunogens. Infect. Immun. 37:271-280.

25. Hancock, R. E. W., A. A. Wieczorek, L. M. Mutharia, and K. Poole. 1982. Monoclonal antibodies against Pseudomonas aeruginosa outer membrane antigens: isolation and characterization. Infect. Immun. 37:166-171.

26. Granoff, D. M., S. J. Barenkamp, and R. S. Munson, Jr. 1982. Outer membrane protein subtypes for epidemiologic investigation of Haemophilus influenzae type b disease. In Haemophilus influenzae: Epidemiology, Immunology and Prevention of Disease. S. H. Sell and P. F. Wright, editors. Elsevier Science Publishing Co., Inc., New York 43-54. 